\title{
Economic Management of Future Nuclear Accidents
}

\section{Tomas Kåberger ${ }^{1}$}

\section{Abstract}

Nuclear core melts with large emissions of radioactive substances are not paid for by nuclear power companies but by the victims and by taxpayers. This subsidy is often the result of legislation with that purpose.

Experience shows that the relative frequency of such accidents is several orders of magnitude larger that the risk estimates publicised by the nuclear industry and nuclear proponents.

This chapter describes the how the problem was created in order to make the nuclear development economically possible. In the end, it is described how a market may be created based on compulsory paying capacity, possibly provided via catastrophe bonds that would internalise many costs of accidents. At the same time, such regulations would provide a market evaluation, by responsible actors, of the nuclear risk costs.

1 Tomas Kåberger, Chalmers University of Technology, Göteborg, Sweden, tomas.kaberger@ chalmers.se

(C) The Author(s) 2019

R. Haas et al. (Eds.), The Technological and Economic Future of Nuclear Power, Energiepolitik und Klimaschutz. Energy Policy 


\section{$1 \quad$ Creating the problem}

As private cars were introduced and became more powerful during the 20th century they created a social problem: People who could readily afford to buy a car, were sometimes unable to pay the costs of the damages they caused when crashing into other cars, people or houses.

The frequency and cost of car accidents, however, were small enough for car drivers to manage the costs by sharing them. Legislation was introduced making traffic insurance compulsory, ensuring that compensation could and would be paid even for very unlikely large accidents. Today, this compulsory payment capacity may be in the order of 1000-100 000 times the price of a car in many countries.

Regarding nuclear reactors, accidents pose a similar problem: Companies may well afford to pay for the construction of a nuclear reactor. Still, they are not able to pay for the damages after a nuclear core has melted and radioactive materials escaped from a broken containment.

This was understood already in the mid 20th century, after the US report on consequences of a major reactor accident was published in 1957. [Beck et al 1957]

In retrospect, this report appears naive as the understanding of the risks of ionising radiation was not well developed. Still, the economic impact of an accident was understood as a so large liability that no private investor would be interested in investing in a nuclear power plant. At the same time there was a common notion that nuclear power was desirable. Therefore, according to dominant actors, economic market conditions should be created to make nuclear investments appear profitable.

Jasper [1989] describes how the nuclear industry asked a group of legal experts to provide a proposal for a legislation that would make nuclear power profitable by socialising the costs of potential accidents.

For car accidents a solution was to share the costs among all car users via mandated insurance. In the nuclear case, a tiny part of the liabilities were shared, but it was necessary to relocate most of the costs outside the nuclear industry.

The report by Murphy et. al [1957] and the resulting Price-Anderson Act have served as blueprints for nuclear accident legislation in most countries with privately owned nuclear power reactors, as well as for international conventions ${ }^{2}$. The key elements are:

1. In case of a nuclear reactor accident the operator of the plant is the only one actor that can be held liable.

2 Most notably the Paris convention on third party liability in the field of nuclear energy. See IEA 1989. 
This reduces the cost of building a reactor, as all suppliers are relieved of the risk that faulty equipment or mistakes during construction may imply economic costs to them, were they to cause a reactor accident. Without this component in the legislation, large companies would refuse to deliver because they either would have to accept high insurance costs, or they would run the risk of bankruptcy if they had delivered something that later was declared the cause of an accident.

2. The economic liability of the operator is strictly limited to an amount far below the potential costs of a major accident.

This component in the legislation has two important aspects. Without a limited accident liability the operator would face bankruptcy in case of a major accident. To banks and others, considering lending money to an operating company, that risk for bankruptcy would be a reason to increase interest rates to compensate for their risk of losing their money in case of an accident. Increased interest rates would lead to higher costs of nuclear power.

An important consequence of this legislation is that the victims of large accidents are without the right to compensation. It is sometimes assumed that the governments, i.e. all people paying taxes in the country where the reactor is operating, take over the full liability. However, this is rarely explicitly stated, as the size of potential accidents is large also in relation to government budgets. It follows that the actual victims of nuclear accidents will carry a large part of the burdens, for example as loss of their habitat.

Deliberately externalising environmental costs is an extraordinary measure in economic policy. Arguments in support of this kind of legislation sometimes illustrate why. In Sweden, the law was based on a government commission that justified this subsidy by arguing "As seen from the statements above, it is necessary to utilise nuclear power - at any cost - if we do not want to accept a lowered standard of living". [SOU 1959:34 p.25]. (In Swedish: "Såsom framgår av det ovan sagda blir vi nödgade att ta atomkraften $i$ anspråk - kosta vad det kosta vill - om vi inte vill acceptera en standardsänkning.")

We may speculate if this blunt expression of illogical economics is a result of the commission secretary intentionally leaving a clear signal to coming generations, or an expression of enthusiastic nuclear zeitgeist beyond rational economic thinking.

Many would claim that this was a decision driven by nuclear weapon ambitions and therefore outside the realm of economic logic.

Regardless of the motives, legislation limiting the liabilities of nuclear actors appears as decisive energy policy. The law had immediate and significant economic implications for the competitiveness of this particular energy technology. It was designed to, and served as, a substantial subsidy. 
In the half century since this legislation was spreading over the world, evidence has accumulated regarding both the frequency of large accidents and the health impact of ionising radiation.

\section{Experience}

The frequency of core melts and of accidents with emissions far exceeds earlier expectations. We now count around ${ }^{3} 10$ nuclear power reactors whose operations were closed after full or partial core melts ${ }^{4}$. Out of these core melt events, Chernobyl and three Fukushima reactors have resulted in significant emissions of radioactive materials.

This experience has come during a period where IAEA estimate the accumulated number of reactor operation years is around 17 000. [IAEA 2017]. So far, the relative frequency of core melts has been one in a couple of thousand reactor-years, while core melts with significant radioactive contamination has been in the order of one in 5000 reactor-years.

Regarding ionising radiation, the series summary reports provided by the International Commission on Radiation Protection, ICRP, now expects roughly 10 times as many cancer cases from a certain collective dose of ionising radiation compared to the estimate in the 1950s.

The scientific issue of health effects of ionising radiation is one of the most intensive scientific controversies as the economic stakes involved are high. One reason is the industrial interests to defend the privilege of legally limited liability. Another, the potential liabilities and political implications of the exposure of people to radiation from nuclear weapons testing ${ }^{5}$. The latter became an issue in

3 The words "around" is used as there are other reactors closed after core damages, while not immediately after, and there are reactors whose status as commercial power reactors are unclear.

4 While definition of core melts as well as which reactors to include among power reactors may be challenged, a rough list may include St Lucens GHHWR in 1966, Bohunice A1 in 1977, TMI 2 in 1979, Chernobyl 4 in 1986, Greifswald 5, and finally three reactors at Fukushima Dai-ichi in 2011. [World Nuclear Association, 2016]. Cochran [2011] also include The Sodium Reactor Experiment, Sankt Laurent A-1 and A-2 as well as Chapelcross-2, but not the Bohunice A1, and ends up with 11 power reactor core melts. There are also non-power producing reactors where core melting has occurred.

5 This is the same kind of scientific controversy as those previously experienced with tobacco smoking and asbestosis. 
1981 when a UN committee estimated nuclear weapon testing being responsible for 150000 premature deaths ${ }^{6}$.

The costs of severe reactor accidents may be in the order of several hundred or even several thousand billions EUR or USD. Costs resulting from such accidents include evacuation of people, health effects among people despite evacuations, costs of limiting emissions of radioactivity, decontamination as well as some sort of decommissioning of the remains of reactors and waste management.

Chernobyl and Fukushima experiences show these costs are not within the capacity of even the largest nuclear operators in the world.

In the Chernobyl case, most of the consequences occurred in Belarus and the Ukraine. As the costs were initially paid out of the Soviet Union budget, most of the resources came from the Soviet republic of Russia. When Russia withdraw from the Soviet Union, they could stop paying, which provided an economic incentive for Russia to dissolve the union. A compilation of incomplete cost assessments are provided by Samets \& Seo 2016. Health effect due to low-level exposure is not included in the cited studies.

Ukraine had difficulties managing the costs of safeguarding the Chernobyl site. Hence, taxpayers in other European countries have been forced to assist in financing the construction of a shelter over the damaged reactor, which would reduce the distribution of radioactivity over the coming 100 years. In order to protect their own interests, the potential victims have been made to pay for prevention.

Fukushima is still in a state where it is impossible to estimate a limit to the costs as the long term strategies to control the radioactivity are not yet fixed. Suzuki et al (2016) estimate costs excluding health effects at almost 100 trillion yen, or 1 trillion US dollar.

Using experience to get a possible order of magnitude of the real risk cost of nuclear reactors, we may combine 100 billion -1 trillion US dollar per accident with a relative frequency of one in 5000 reactor-years which would give an average risk cost of 20-200 million dollar per reactor-year. With reactors producing 5-10 $\mathrm{TWh} /$ year this would provide a range from $0.2-4$ cent $/ \mathrm{kWh}$. Despite enormous uncertainties the accumulated experience suffices to dismiss the idea that the risk costs are "clearly negligible".

The argument that externalising the costs of accident risks is acceptable because the risk costs are negligible is not consistent with experience.

The question is instead how to manage this risk costs in a rational way.

6 United Nations Comprehensive Study on Nuclear Weapons 1981, p 86, § 260 


\section{$3 \quad$ Managing nuclear risk}

Often, a risk of lost property that is large for the actor exposed, is managed by an insurance system. When there is a large economic risk for third parties, such as with car accidents, the insurance system is made compulsory ${ }^{7}$.

In an insurance market, voluntary actors use experience and other relevant information to reach a price for the risk, and the actors offering to share the risk, normally insurance companies, become economically liable for the outcome.

For nuclear accident risks, the analogy with the compulsory car insurance system is, however, not immediately applicable. The reason is that insurance companies are not able to cover damages of the magnitude of nuclear accidents. With less than 500 nuclear power reactors in the world, the owners of reactors cannot finance an insurance system by themselves. This argument has been used to claim that a compulsory insurance is not possible.

However, it is possible to find insurance systems that do not rely on traditional insurance companies. Such systems have been developed to manage natural disasters and other rare catastrophes. Radetzki \& Radetzki [2000] describe how catastrophe bonds ${ }^{8}$ could be used for nuclear accident liabilities.

Operators could be forced to pay for catastrophe bonds to collect capital enough to compensate victims of large accidents. Such bonds would be normal interest bearing bonds, were those who provide capital are offered an extra premium on the condition that the bond value is used to cover the cost of the catastrophe in question if realised. Using the catastrophe bond market opens access to relevant magnitude of capital to cover also large nuclear accidents, and the premium paid by the reactor operators would provide a measure of the accident risk.

Creating the market would include specifying the kind of costs to be covered caused by an accident. Property costs, compensations for evacuations are directly payable to the victims. What may be significant costs for health effects will not be individually identifiable but may occur as large economic burdens on health, or medicare, insurance systems. This liability may then be payable to the health insurance systems rather than to individuals, even when individual suffering may be a significant part of the economic impact.

7 The reason for a compulsory insurance is that the responsible actor may lack paying capacity. Electric Power Companies may be very large, but no EPC is large enough to manage a large reactor accident. Even more important is that EPCs often organise nuclear power plants in separate limited liability companies to avoid liability for other risks including future waste and decommissioning costs.

8 For a definition of catastrophe bond, see Investopedia 2017. 
Another relevant issue in the regulation is how large the required paying capacity shall be. This may prove an important issue if the paying affects every provider of capital for any accident. As described by Radetzki \& Radetzki I have also earlier suggested that a solution that reduces the importance of this capacity decision I have presented is to make the catastrophe bonds consecutive rather than exchangeable. Consecutive bonds would be specified so that one bond may be used to cover cost between 1000 M USD and 1001 M USD, while another bond would only be used if the accident cost more than $1001 \mathrm{M}$ USD to cover the next million. The former may be expected to cost more than the latter, as the probability of the larger accident is lower than the probability of the smaller.

Under such a regime of consecutive bonds the importance of the level of required capacity may be reduced as the cost of marginal bonds would be small when reaching trillions of USD.

By introducing compulsory arrangements of this kind, a market value would be created for nuclear accident risks. Political debates on probabilities and effects would be replaced by professional assessments made by parties who would have to assume economic responsibility for their assessments. This is likely to result in more scientific assessments of risks and their economic value.

\section{$4 \quad$ Possible consequences, and imperfections}

The obvious consequence of a compulsory insured paying capacity for third party liabilities, is that the operators would pay a market price of the risk costs. This would reduce their competitiveness in relation to other energy technologies.

Still, this proposal is embraced by many pro-nuclear spokespersons as they expect the assessment in the market will be that most nuclear reactors are so safe that the risk costs are small. Paying a small amount to cover the full accident liability would be a low price to do away with the political arguments of accident risks.

At the same time nuclear critics find the proposed market solution palatable as they are convinced the price for nuclear catastrophe bonds would be so high reactors would be out-competed by modern renewable energy alternatives.

There have been some critical arguments. Swedish nuclear opponent Eija Liljegren-Palmær has argued that the nuclear industry has such an advantage regarding access to information that they would be able to mislead representatives of financial institutions, such as pension funds, to accept theoretical calculations with too small premiums. Instead of misleading politicians representing tax payers, they would mislead those managing the same tax-payers pension funds. 
Such a risk cannot be disregarded. When Compulsory, government controlled pension funds are involved the risk is similar.

However, often pension funds are managed without pro-nuclear policy objectives. Further, markets would allow individuals or groups to withdraw their money from funds they see exposing them to risks. Thus there would at least be more of voluntary risk taking then after parliamentary majority decisions.

However, there are proponents who would say that the hysteria around radiation is making the assessments biased so as to over-estimate risk costs. Here, the response is that the nuclear industry only has to find a sufficient number of financial actors who see the realistic risks to buy the required paying capacity via the bond market. The required capacity is likely to be small compared to potential global capital markets.

There is a risk in both directions that lack of information or ignorance may result in decisions resulting in misleading pricing of the accident risks. However, some may lose a small potential income as they over estimate risks. To others entering the marked via misinformed decisions may lose their assets. Still, the victims and taxpayers are not affected, as those who voluntarily took on the risks will carry both the economic liability and guarantied paying capacity.

For electricity consumers a demand on full paying capacity would not have a significant effect on electricity prices. In the short term this is true as nuclear power rarely provide the marginal, price setting generation. In the longer term, the set of different generation technologies now available at similar costs is providing many alternatives, and in most parts of the world nuclear is clearly not an option when considering new capacity.

If the market evaluation of the risk turns out low enough, reactors would continue to operate and the insurance would not affect short term marginal cost and therefore not the electricity price.

If, however, the risk cost was high and reactors forced out of the market, the cost of renewable energy has lately proven so low that the price effect would also be small.

As described elsewhere, [Kåberger 2001], this reform may come together with the internalisation of fossil fuel externalities. Making fossil fuelled generators pay for local air-pollution and greenhouse gas emissions would initially have a greater effect on electricity prices as fossil fuelled power often constitute price-setting marginal generation. An important reason to do both is that nuclear power under a carbon pricing regime may be ably to continue operating with higher risk costs than in a situation without pricing emissions from fossil fuelled generators in the short term. 


\section{Conclusion}

Experience shows that currently prevailing regulation of nuclear accident liabilities is a significant subsidy to nuclear power. As new, renewable energy supply is economically competing with existing nuclear power, re-regulating accident liability will have importance for the rate of decommissioning nuclear reactors and therefore also for the number of reactor accidents in the future.

Experience of large reactor accidents with significant emission of radioactivity has shown that even the most endowed reactor owners are unable to compensate the victims. Governments concerned also have had great difficulties in meeting the need for compensation. In the Chernobyl case tax payers of other countries have even stepped in to subsidise the mitigation of the consequences.

The experience of reactor owners creating significant costs they are unable to compensate, has proved to be a problem similar to when the owners of cars caused damages beyond their paying capacity.

In the current era of competitive electricity markets this opportunity appears all the more urgent for markets to find the efficient rate of change of power supply.

As the catastrophe bond concept and market was developed by the end of the 21st century it has become possible to address the problem of large nuclear accidents by making it compulsory for anyone operating a nuclear reactor to be able to pay for the consequences of large accidents. As with cars, the required paying capacity may be orders of magnitude higher then the cost of building a reactor, but the societal problem of rolling-off external costs on citizens and communities around nuclear accident sites can be addressed to some degree.

\section{References}

Beck, C.K. et al., 1957: Theoretical Possibilities and consequences of major accidents in large nuclear power plants - a study of possible but highly improbable, were to occur in large nuclear plants. United States Atomic Energy Commission. Washington.

Cochran, Thomas B., 2011: Statement before the US senate on the Fukushima Nuclear Disaster and its Implications for 'us Nuclear Power Reactors. https://www.energypolicyblog. com/2011/04/27/reassessing-the-frequency-of-partial-core-melt-accidents/

Investopedia, 2017: Catastrophe Bond. http://www.investopedia.com/terms/c/catastrophebond.asp

Jasper, J., 1990: Energy and the State: Nuclear Politics in the United States, Sweden and France. Princeton University Press.

IAEA, 2017 https://www.iaea.org/pris/ viewed 2017-03-11. 
Kåberger, T., 2002: Swedish Nuclear Power and Economic Rationalities. Energy and Environment, Vol. 13, No. 2 pp 185-200.

Murphy, A.W. et al., 1957: Financial protection against atomic hazards. Atomic Industrial Forum, Inc. New York.

OECD, 1994: Liability and Compensation for Nuclear Damage - An International Overview. OECD, Paris.

Radetzki M. \& Radetzki M., 1997: The Liability of Nuclear and Other Industrial Corporations for Large- Scale Industrial Damages Journal of Energy \& Natural Resources Law, Vol. 15, No. 4.

Radetzki M. \& Radetzki M., 2000: Private Arrangements to Cover Large-Scale Liabilities Caused by Nuclear and Other Industrial Catastrophes. Geneva Papers on Risk and Insurance, Vol. 25 No 2, April 2000.

Samet, J.M. \& Seo, J., 2016: The Financial Costs of the Chernobyl Nuclear Power Plant Disaster: A Review of the Literature. http://www.greencross.ch/wp-content/uploads/ uploads/media/2016_chernobyl_costs_report.pdf

Suzuki, T et.al., 2016: Aiming at a Low Carbon Society in Japan by 2050: Impact of the Fukushima Nuclear Accident and COReduction Target Economics of Energy \& Environmental Policy, Vol. 5, No. 1.

IEA, 1989: Paris convention on third party liability in the field of nuclear energy. https:// www.oecd-nea.org/law/pubs/1989/154-paris_third_party_brussels_conv.pdf

SOU, 1959:34 Om atomansvarighet. (On nuclear liability)

SOU, 1994:107/108 Kärnbränslefondsutredningen

United Nations, 1981: Comprehensive Study on Nuclear Weapons. Department of Political and Security Council Affairs. United Nations Centre for Disarmament. Report of the Secretary-General. https:/unoda-web.s3-accelerate.amazonaws.com/wp-content/uploads/ assets/publications/studyseries/en/SS-1.pdf

WorldEnergyAssociation, 2016: Decommissioning Nuclear Facilities. http://www.world-nuclear.org/information-library/nuclear-fuel-cycle/nuclear-wastes/decommissioning-nuclear-facilities.aspx, as of November 2016.

Open Access This chapter is licensed under the terms of the Creative Commons Attribution 4.0 International License (http://creativecommons.org/licenses/by/4.0/), which permits use, sharing, adaptation, distribution and reproduction in any medium or format, as long as you give appropriate credit to the original author(s) and the source, provide a link to the Creative Commons license and indicate if changes were made.

The images or other third party material in this chapter are included in the chapter's Creative Commons license, unless indicated otherwise in a credit line to the material. If material is not included in the chapter's Creative Commons license and your intended use is not permitted by statutory regulation or exceeds the permitted use, you will need to obtain permission directly from the copyright holder.

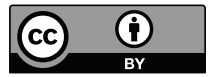

